\title{
Cellulases from Extremophiles
}

\author{
Giorgi Kvesitadze* \\ Durmishidze Institute of Biochemistry and Biotechnology of Agricultural University of Georgia \\ 0159, Georgia
}

Submission: April 12, 2017; Published: May 30, 2017

"Corresponding author: Giorgi Kvesitadze, Agricultural University of Georgia, Durmishidze Institute of Biochemistry and Biotechnology, Georgia, Email: g.kvesitadze@science.org.ge

\begin{abstract}
Enzymatic hydrolysis of cellulose to fermentable glucose is the most important technological process among all possible enzyme technologies. Thermophilic fungi are potential sources of enzymes with scientific and commercial interests. From the collection of microscophic fungi isolated from ecological niches of Georgia at S.Durmishidze institute of Biochemistry and Biotechnology of Agricultural University thermophilic micromycetes -active producers of stable cellulases has been selected. Four endoglucanases were purified to homogeneity from Sporotrichum pulverulentum, Aspergillus wentii, Aspergillus versicolor, Chaetomium thermophile culture medium. Some kinetic, physical and chemical properties of purified engodlucanases (Molecular mass, isoelectric point, carbohydrates content, $\mathrm{pH}$, temperature optimums, Km, Kcat, Vmax, Ki, Henries constant $K_{p}$, substrate specificity) has been studied.
\end{abstract}

Keywords: Microscophic fungi; Endoglucanase; Thermopile; Hydrolysis; Purification

\section{Introduction}

Continually synthesis of structural polymers such as: cellulose, hemicelluloses, starch, pectin, etc., and no carbohydrate polymer lignin is characteristic for the great majority of higher plants. Enzymes hydrolyzing or oxidizing these polymers are found in plants [1] but the equilibrium of their hydrolysis and/ or oxidative degradation is so strongly shifted toward their synthesis that hydrolysis becomes negligible process and shouldn't be taken into consideration. Constitutive components of plant-soil system-microorganisms and namely the majority of mycelia fungi genera are characterized by high activities of plant biopolymers degrading enzymes. Enzymatic hydrolysis of cellulose, which is the main component of plant mass (makes up to $60 \%$ of all plant mass) to fermentable glucose, is the most important technological process among all possible enzyme technologies [2,3]. Microorganisms such as thermophiles, halophiles, acidophiles, alkaliphiles, etc. often are capable to produce enzymes exceeding in stability currently used ones $[4,5,6]$. Investigation of extremophiles of different taxonomic groups allows isolating strains-extremophiles producing well balanced stable molecules of enzymes, having increased resistance against different critical conditions and so much required in a number of industrial processes [7,8,9]. Special interest attracts thermophilic/thermotolerant fungi having potential of growth above $20^{\circ} \mathrm{C}$ and optimum of growth 40 $50{ }^{\circ} \mathrm{C}$ and very rear at $55-65^{\circ} \mathrm{C}$. Fungi thermophiles represent heterogeneous physiological group of various genera in the
Phycomycetes, Fungi Imperfecti, Ascomycetes, and Mycelia sterilia [10]. The aim of present investigation was the selection of extreme thermophilic strains as a new isolates and from existing fungi collection and evaluation of their cellulose degrading enzymes according to heat stability and salient physical-chemical characteristics.

\section{Materials and Methods}

Soils, plants, and thermal springs from the most hot places of western (subtropical), eastern (steppe), and southern soilclimatic zones of Georgia were used as sources for isolation of mycelial fungi strains. The procedure of fungi strains isolation was performed from primary plating on $8 \%$ agar containing medium. The fungi were cultivated in deep conditions at 35-55 ${ }^{\circ} \mathrm{C}$ for ten days. The strains were cultivated on the following nutrient mediums containing (in \%): microcrystalline cellulose-1,0; corn extract-0,05; $\mathrm{NaNO}_{3}-0,36 ; \mathrm{KH}_{2} \mathrm{PO}_{4}-0,2 ; \mathrm{MgSO}_{4}$ 7H20-0,05. Medium2, microcrystalline cellulose-20; corn extract-0,05; $\mathrm{KH}_{2} \mathrm{PO} 4-0,68 ;\left(\mathrm{NH}_{4}\right) 2 \mathrm{SO}_{4}-0,13 ; \mathrm{MgSO}_{4} 7 \mathrm{H}_{2} \mathrm{O}-0,56$; $\mathrm{CaCl}_{2}-0,2$. The strains were grown in Erlenmeyer flasks with 250 or $750 \mathrm{ml}$ on a shaker $180-200$ rapids/min in a 301 fermenter (New Branswick, USA). Viscozimetric activity was determined as a result of enzyme action on soluble $\mathrm{Na}-\mathrm{CMC}$ according to method modified by Rodionova et al. [11]. Filter paper activity was determined by the method of Ghose [12], based on cellulase to perform hydrolysis of filter paper oligosaccharides, the amount 
of reducing sugars were estimated according to Adney \& Baker [13]. For the determination of cellobiohydrolase activity was used the method offered by Nummi et al. [14] with amorphous cellulose as a substrate. Toxicity of strains was determined according to [15]

\section{Results and Discussion}

Mycological studies exposed the most frequently met genera in various substrates of Georgia: Mucor, Rhizopus, Chaetomium, Allescheria, Malbranchea, Botrytus, Monilia, Aspergillus, Penicillium, Sporotrichum, Trichoderma, Trichotecium, Alternaria, Cladosporium, Helmintosporium, Fusarium and the order Mycelia Sterilia. Systematic analysis exposed the existence in collection strains of Ascomycetes, Basidiomycetes, Zygomycetes, Deuteriomycetes, Mycelia Sterilia. Among the collection strains it was found the existence toxic strains (up to 20\%). In majority of the cases they produce different set of cellulases some strains actively form such extracellular enzymes as: xylanase, laccase, $\mathrm{Mn}$ peroxidase, alfa- and glucoamylases, acid and neutral proteases, pectinases, invertase, alfa-galactosidase, etc. Tests for thermophilicity, performed by determining of growing potential of strains between $30-60{ }^{\circ} \mathrm{C}$, showed that $6 \%$ of all strains could be considered as thermophiles/thermotolerants. The representatives of following genera: Mucor, Aspergillus, Chaetomium, Allesceria, Malbranchea, Sporotrichum the most frequently displayed this property. Finally, the collection of fungi thermophiles accounting 36 strains, actively growing between $40-45{ }^{\circ} \mathrm{C}$ on glucose, glycerol and xylose has been created. The most thermophilic strains, in particular Allecheria terrestris and Chaetomium thermophile grows well at $42-45^{\circ} \mathrm{C}$, Sporotrichum pulverulentim at $40{ }^{\circ} \mathrm{C}, \mathrm{A}$. versicolor and $A$. wentii at $42^{\circ} \mathrm{C}$. The cellulase system in fungi cultures comprise three cellulases: enzymes endo- $(1,4)-{ }^{2}$-D-glucanase (endoglucanase), exo-(1,4)${ }^{2}$-D--glucanase (cellobiohydrolase), $\beta$-- glucosidase. It should be underlined that not all thermopiles are characterized by production full set of cellulases. As it has been determined above $90 \%$ of all cellulase activities were extracellular, so further only extracellular activities will be discussed concerning the cellulase production potential of strains. The activities of cellulases of cultural filtrates are shown in (Table 1).

Table 1: Extracellular activities of fungi thermophiles while their deep cultivation.

\begin{tabular}{|c|c|c|c|c|c|}
\hline \multirow{2}{*}{$\#$} & \multirow{2}{*}{ Strain } & \multicolumn{4}{|c|}{ Activity un/ml } \\
\cline { 3 - 6 } & Endoglucanase & CMC & FP & $\begin{array}{c}\boldsymbol{\beta} \\
\text { Glucosidase }\end{array}$ \\
\hline 1 & A. versicolor & 23.5 & 19.7 & 0.8 & 0.59 \\
\hline 2 & A. wentii & 18.5 & 15.3 & 0.68 & 0.5 \\
\hline 3 & A. terreus & 4.1 & 11.5 & 0.5 & 0.5 \\
\hline 4 & $\begin{array}{c}\text { Sp. } \\
\text { Pulverulentum }\end{array}$ & 10 & 8.7 & 0.3 & - \\
\hline 5 & Ch. Termopile & 1.5 & 1.2 & 0.1 & 0.5 \\
\hline 6 & $\begin{array}{c}\text { Allesheria } \\
\text { terrestris }\end{array}$ & 3.3 & 1.7 & 0.2 & 0,3 \\
\hline
\end{tabular}

Some specificities of fungi-thermophiles in production of cellulases was clearly expressed while their deep cultivation. For instance the absence even in traces amount of $\beta$-glucosidase in cultural filtrate of Sporotrichum pulverulentum strain should be considered as anomalous. The complete absence or very low activity of extracellular cellobiohydrolase activity in cultural filtrates of thermophiles indicate on different mechanisms of cellulose enzymatic break down performed by extracellular preparations isolated from thermophiles but it should not be considered as a common characteristic for all fungi thermophiles. Estimation of thermo stability of selected cellulases was done on further stage via the kinetic curve of thermo inactivation. Incubation of enzyme solution was carried out without a substrate at $65{ }^{\circ} \mathrm{C}$, within 300 minutes, in order to study the kinetics of thermo inactivation. Enzyme activity was estimated by the standard methods at particular intervals of time, and was calculated by the formula A/A0 • $100 \%$, were A0 is an initial activity, and A - residual activity in t-period of time. Kinetics of thermo inactivation of one and the same enzyme was compared in thermophils and mesophylls, in particular, with the enzyme of Trichoderma reesei commercial preparation -Onozuka R. Kinetics of thermo inactivation of enzyme preparations according to filter paper activity is shown on Figure 1. The same results, have been received while analyzing heat inactivation of cellulases according to CMC activity. Generally, it should be considered that cellulases from thermophilic fungi are more heat-stable enzymes than their mesophilic analogues. At the same time cellulase of Georgian thermophilic strains attract interest due to their unusual properties. For instance, as it has been mentioned, cellulase preparation from $S$. pulvrulentum does not contain cellobiohydrolase and $\beta$-glucosidase activities but as a result of 40 minutes incubation (exhausted hydrolyses) on crystalline cellulose in reaction mixture is liberated the detectable amount of glucose. With the aim to compare the endoglucanases from thermophilic fungi endoclucanases from different genera were purified and determined some of their molecular characteristics

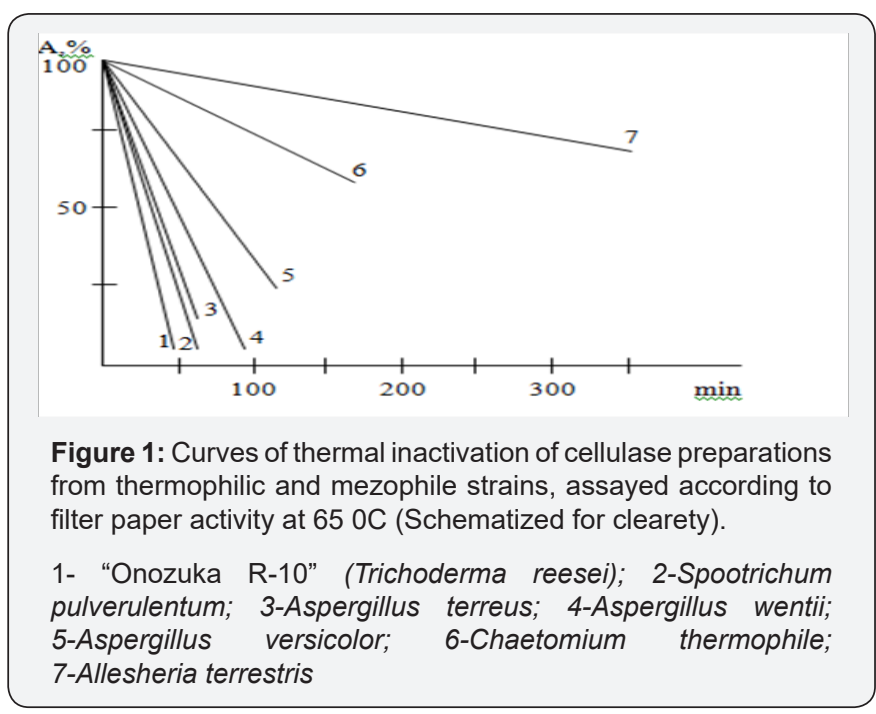


Purification of Endoglucanases.

Table 2: Purification of endoglucanases from deep culture of A. versicolor D1

\begin{tabular}{|c|c|c|c|c|c|c|}
\hline \multicolumn{2}{|c|}{ Stages of purification } & $\begin{array}{c}\text { Total activity } \\
\text { units }\end{array}$ & Total protein mg & $\begin{array}{c}\text { Specific activity } \\
\text { unit/mg }\end{array}$ & $\begin{array}{c}\text { Degree of } \\
\text { purification }\end{array}$ & $\begin{array}{c}\text { Retained activity } \\
\%\end{array}$ \\
\hline \multicolumn{2}{|c|}{ Initial enzyme preparation } & 2500 & 550 & 4.5 & 1 & 100 \\
\hline \multicolumn{2}{|c|}{ DEAE (Zeta Prep) disk } & 2150 & 90 & 23.8 & 5.3 & 86 \\
\hline \multicolumn{2}{|c|}{ SP (Zeta Prep) disk } & 1950 & 70 & 28 & 6.2 & 78 \\
\hline \multirow[t]{2}{*}{$\begin{array}{l}\text { Gel filtration } \\
\text { HW-55 }\end{array}$} & E1 & 350 & 8 & 43.7 & 9.7 & $\mathrm{I}-14$ \\
\hline & E2 & 1090 & 10 & 109 & 24.2 & II-43.6 \\
\hline \multirow[t]{2}{*}{$\begin{array}{l}\text { DEAE- } 650 \\
\text { Toypearl }\end{array}$} & E1 & 325 & 5.5 & 59 & 13.1 & $\mathrm{I}-13$ \\
\hline & E2 & 450 & 1.8 & 250 & 56 & II-18 \\
\hline
\end{tabular}

Purification of endo-1,4- $\beta$-D-glucanases from thermphilic fungi has been performed according to special methodology work out for this group of enzymes. The common scheme of enzymes purification consists from following stages: ion exchange chromatography on DEAE Toyepearl, CM-650 Toyepearl, gelfiltration (HW-55), rechromatography on DEAE-Toyepearl. Using this methodology endo-1,4- $\beta$-D-glucanases from the following thermophilic fungi strains have been purified to homogenous state: A. versicolor (Degree of Purification 56), A. wentii (D.P.93), S. pulverulentum (D.P.82), Chaetomium thermophile (D.P.46). Below Table 2, are presented the stages of purification of endo-1,4- $\beta$-D-glucanase from $A$. versicolor, with corresponding characteristics for each stage of purification. As a result of above shown purification scheme, endo-1,4- $\beta$-D-glucanase produced by $A$. versicolor was received in a highly purified state and divided on two fractions, the main one equal to $43 \%$ of initial activity and minor $13 \%$ of initial activity. Finally the main fraction exposes protein homogeneity by disk electrophoresis. The existence of homogenous endo-1,4- $\beta$-D-glucanases from A. wentii, S. pulverulentum, and Chaetomium thermophile have also been detected as a result of the same purification methodology. Some Physical-chemical characteristics of homogenous endoglucanases were studied.

\section{Adsorption}

Formation of strongly bonded cellulase-cellulose complex [ES] is extremely important for successful hydrolyses of insoluble cellulose. Concluding from the postulate: "Better links - better catalysis", high degree of enzyme adsorption on a substrate greatly determines it's technologibility [16]. Therefore the process of adsorption of endoglucanase preparations and homogenous endoglucanase on insoluble substratemycrocristalline cellulose was studied by the modified method of Rabinovich [17]. Calculation of the relative content $(\alpha)$ and coefficient of distribution (Kp) of weakly and firmly adsorbed forms on MCC showed, that A.wentii preparation contains 33\% of weakly adsorbed endoglucanase with coefficient of disstribution Kp (constant Henry)-0,031g/L and 67\% of firmly adsorbed one with $\mathrm{Kp}-0,83 \mathrm{~L} / \mathrm{g}$. Sp. pulverulentum preparation contains $20 \%$ of weakly adsorbed endoglucanase with Kp- 0,008 L/g and 80\% of firmly adsorbed one with coefficient of disstribution $0,92 \mathrm{~L} / \mathrm{g}$. Chaeomium thermophile preparation contains of $38 \%$ of weakly adsorbed endoglucanase with Kp-0,006L/g and 62\% of firmly adsorbed one with coefficient of distribution- $0,656 \mathrm{~L} / \mathrm{g}$. The preparation of $A$. versicolor has a very strongly adsorbed form of endoglucanase- $98 \%$ with $\mathrm{Kp}-1,6 \mathrm{~L} / \mathrm{g}$. The study of adsorbtive characteristics of homogenous endoglucanases illustrated their homogeneity according to the stability to adsorb on MCC (Table 3).

Table 3: Adsorptive characteristics of crude and homogenous endoglucanases on CMC.

\begin{tabular}{|c|c|c|c|c|}
\hline Strain & Kp L/g & \% & Kp l/g & Weakly adsorbed form \\
\hline A.wentii & Firmly adsorbed form & & 0.031 & 33 \\
\hline Sp.pulverulentum & 0.83 & 67 & 0.008 & 20 \\
\hline Ch. thermophile & 0.92 & 80 & 62 & \\
\hline A. versicolor & 0.656 & 98 & & 38 \\
\hline Homogenous & 1.6 & & & \\
\hline A. wentii & 1.8 & & & \\
\hline Sp.pulverulentum & 1.6 & & & \\
\hline Ch. thermophile & 1.9 & & & \\
\hline A. versicolor & 2.2 & & & \\
\hline
\end{tabular}


The pH- optimums of endoglucanases were determined by estimating the enzyme activities in a reaction mixture with different pH buffers (2.5-9.0) under standard assay conditions. Estimations of endoglucanase activities at different temperature $\left(40-70{ }^{\circ} \mathrm{C}\right)$ were carried under standard assay conditions too. The Michaelis-Menten constant $(\mathrm{Km})$ and maximal reaction velocity (Vmax) of purified endoglucanases were determined by measuring the enzyme activity with CMC in concentrations ranging from 1 to $10 \mathrm{mg} / \mathrm{ml}$. From the double-reciprocal plots, Kinetic constants were calculated according to LineweaverBurk plot. The molecular mass of purified endoglucanases was estimated by $12 \%$ sodium dodecylsulfate polyacrylamide gel electoctrophoresis as described laemmli [18]. High and low molecular weight standards (Sigma) were used to determine molecular weight of enzymes. The gel was stained by silver staining method. A plot of log molecular weight of the standard protein markers against relative mobility gives the molecular weight of protein. Analytical thin-layer gel isoelectric focusing was performed in the $\mathrm{pH}$ range of 3.5-9.5. After electro focusing, the gel was fixed in solution containing a methanol/acetic acid solution. Later, it was silver-stained. The pI of endoglucanase was determined using the plot of relative mobility of standard protein markers versus their pI. Inhibition of endoglucanase by glucose was determined in presence of dyed cellulose "DC-31" as substrate in various quantities (2.5-12.5g/l). Inhibition constants (Ki) were determined from corresponding Linewearver-Burk plots using standard linear regression techniques [19]. All studied endoglucanases were weakly, noncompetitive inhibited by reaction products. The carbohydrate content of purified endoglucanases was determined by the phenol-sulphuric acid method [20]. Some Physical-chemical characteristics of Table 4: Salient characteristics of endoglucanases from thermophilc fungi

\begin{tabular}{|c|c|c|c|c|c|}
\hline$\#$ & Molecular properties & $\begin{array}{c}\text { A. } \\
\text { versicolor }\end{array}$ & $\begin{array}{c}\text { A. } \\
\text { wentii }\end{array}$ & Sporotrichum pulverulentum & Chaetomium termophile \\
\hline 1 & Molecular mass (kDa)MM & 51 & 55 & 45 & 50 \\
\hline 2 & Isoelectric point $(\mathrm{Pi})$ & 4.7 & 4.6 & 4.5 & 4.7 \\
\hline 3 & Carbohydrates content (\%) & 22 & 18 & 6.7 & 21 \\
\hline 4 & Specific activity (units/mg. protein) & 250 & 190 & 205 & 40 \\
\hline 5 & pH- optimum & 4 & 4.2 & 4.5 & 4.5 \\
\hline 6 & Temperature optimum, 0C & 60 & 60 & 55 & 65 \\
\hline 7 & $\mathrm{Km}(\mathrm{mM})$ & 2.2 & 2.8 & 2.5 & 3 \\
\hline 8 & Kcat (sec-1) & 45 & 43 & 21 & 33 \\
\hline 9 & K sp.Kcat/Km (M-1 min-1) & 18 & 15 & 9 & 11 \\
\hline 10 & $\operatorname{Vmax}(\mu \mathrm{M} / \min . \operatorname{ml})$ & 74 & 71 & 56 & 66 \\
\hline 11 & Ki (gr/l) & 105 & 99 & 72 & 112 \\
\hline 12 & Henries constant $\mathrm{Kp}(1 / \mathrm{g})$ & 2.2 & 1.8 & 1.6 & 1.9 \\
\hline
\end{tabular}

\section{Substrate Specificity}

The action of highly purified endoglucanases of thermophilic fungi on different compounds having $\alpha$ and $\beta$ - bonds: CMC, amorpouscellulose, lichenin, galactane, arabinan, galactomannan, avicel, laminarine, mannan, cellobiose, para-nitrophenyl homogenous endoglucanases are given in Table 4. As seen from the data of the Table 4. The molecular masses of endoclucanases from different genera of thermophilic fungi are between 45$55 \mathrm{kDa}$ and correspond to literature data for endoglucanases of thermophilic fungi having masses from 30 to $100 \mathrm{kDa}[21,22]$. The great similarity in isoelectric points (Pi) has been exposed for all four enzymes (4.5-4.7), which also correlate with published data [23]. Temperature optimum of enzymes action depending on the prolongation of time of enzyme action is always discussible. In our experiments the hydrolysis of filter paper was continued for one hour, for endoglucanase from A. versicolor and A. wentii temperature optimum of action was equal to $600 \mathrm{C}$, for the strain Chaetomium termophile in the same conditions $65^{\circ} \mathrm{C}$, and only the endogucanase of Sporotrichum pulverulentum has optimum of enzyme action below $60^{\circ} \mathrm{C}$. There is in literature one publication indicating on highest temperature optimum of endoglucanese from thermophilic fungi Talaromyces emersonii lying between $75-80{ }^{\circ} \mathrm{C}[24]$, in others the temperature optimum of action does not exceed $65^{\circ} \mathrm{C}(25.26)$. The content of carbohydrates for the heat stability of fungal endoglucaneses might be quite important for the stabilization of molecule. First of all even slightly heat stable endoglucanases contain carbohydrates in different quantity [27.28] and the content of carbohydrates in the most stable endoglucanases is equal to 30 , 45 and 50\% [4]. Content of carbohydrates in endoglucanases of experimented strains was quite similar $18-22 \%$, with the exception of endoclucanase of Sporotrichum pulverulentum equal 6,7 pH optimum of action for the great majorities of fungal endoglucanases (for both, mesophiles and thermophiles) lays in slightly acidic area (4.0-5.8).

galactopyranoside has been investigated. Concentration of substrates in reaction mixture was from 1.5 up to $7 \mathrm{~g} / \mathrm{l}$. Activities of the enzymes has been detected according to liberated (formed) reducible sugars. The time for the enzymatic hydrolysis reaction was from 10 minutes to 72 hours. According to the obtained 
data all enzymes are characterized by great similarity of action on different bonds in substrates. Endoglucanases of thrmophilic fungi easily hydrolyze $\beta-1.4$ bonds in carboxymetylcellulose. Their action is detectable (measurable) on following substrates: amorphous cellulose ( $\beta$-1.4- bonds), lichenin ( $\beta$-1.4- and $\alpha-1.3)$, galactane $(\beta-1.4-)$ and mannan $(\beta-1.4-)$, expose trace activities while action on galactomannan ( $\beta-1.4$ and -1.6), laminarin $(\alpha-1.3)$, mannan $(\alpha-1.3)$ and do not act on arabinan ( $\beta-1.5)$, cellobiose, para-nitrophenyl-galactopyranoside, as well as on para-nitrophenyl-glucopyranoside. So it could be suggested that endoglucanases of fungi thermophiles actively cleave $\alpha-1.4$ bonds in polysaccharides, have trace activities on $\alpha-1.3$-bonds, and do not act other $\beta$ - or any $\beta$-bonds in small or high molecular substrates [25-27].

\section{Hydrolysis.}

It has been stated that at the action of homogenous endoglucanases of A. wentii, A. versicolor, S. pulverulentum, Ch. thermophile on nonsluble MCC substrate for 72 hours (temperature of incubation $-55^{\circ} \mathrm{C}$, (MCC) $-5 \mathrm{~g} / \mathrm{L}, 0.05 \mathrm{M}$ acetate buffer $\mathrm{pH} 4.5$ ) the degree of conversion is $68 \%, 75 \%, 48 \%, 27 \%$ respectively, and that on amorphous cellulose for 45 hours $\left(55^{\circ}\right.$, (MCC)- 2g/L, $0.05 \mathrm{M}$ acetate buffer $\mathrm{pH} 4.5$ ) -82\%, 87\%, 75\% and $52 \%$ respectively. Chromatodraphic (HPIC "Waters") analysis of crystaline substrate hydrolysis products by homogenous endoglucanases showed that hydrolysis products contain glucose, cellobiose, cellotetraose. According to the results of hydrolysis (48 hours, (S)-1g/10ml) of different cellulose containing agrarian wastes (tea, tobacco, wine, beet, citrus) by endoglucanase preparations yield of reducible sugar was 24$58 \%$, yield of glucose $16-30 \%$.

\section{References}

1. Reginado A, Toni O C, Wagner (2007) Plant Physiology V (19): 1013.

2. Moxley G, Zhu Z, Percival Zhang Y H (2008) Agric. Food Chem 56(17): 7885-7890.

3. Talebnia F, Karakashev D, Angelidaki I (2010) Production of bioethanol from wheat straw: An overview on pretreatment, hydrolysis and fermentation. Bioresource Technology V 101(13): 4744-4753.

4. Maheshwari R, Bharadwaj G, Bhat MK (2000) Thermophilic fungi: their physiology and enzymes. Microbiology and Molecular Biology Reviews 64(3): 461-488.

5. Kvesitadze G, Svanidze R, Tsuprun V, Nizharadze D, Chirgadze L, et al. (1990) Russian Journal of Bioorganic Chemistry 16(7): 461-488.

6. Pabulo Henrique Rampelotto (2010) Resistance of Microorganisms to Extreme Environmental Conditions and Its Contribution to Astrobiology. Sustainability 2(6): 1602-1623.

7. Viikari L (2007) Lignocellulosic enzymesAdvances in Biochemical Engineering Biotechnology 121-145.

8. Farrell AE, Plevin RJ, Turner BT, Jones AD, O'Hare M, et al. (2006) Ethanol can contribute to energy and environmental goals. Science 311: 506-508.

9. Shafer T, Duffer F, Borchet T (2000) Proceeding of the IIICongress of Extremophiles, Hamburg, Germany, 306-307.

10. Maheshwari R, Bharadwaj G, Bhat K (2000) Thermophilic fungi: their physiology and enzymes. Mol BiolRev 64(3): 461-488.

11. Rabinovich M, Klesov A, Berezin I (1977) Physical Chemistry research for Engineering and applied sciences. Bioorganic Chemistry V 3: 405414.

12. Ghose T, (1987) Measurement of cellulase activities. Pure Apply Chemistry 59: 257-268.

13. Adney B, Baker J (1996) Laboratory Analytical Procedure (LAP) Issue

14. Nummi M, Niku-Paavola M, Lappalainen A, Enari T, Raunio VC (1984) Biochemical Journal 215(3): 67783.

15. Diekman M, Green Ml (1992) Mycotoxins and reproduction in domestic livestock. J Anim Sci 70(5): 1615-1627.

16. Singh PA, Kumar, Schugeri K (1991) Journal of Biotechnology V 18(3): 205-212.

17. Rabinovich M, Chernoglasov B, Klesov A (1983) Biochemistry V48: 369-378( in Russian)

18. Laemmli U (1970) Nature 227: 680-685.

19. Nutsubidze N, klesov A, Todorov P (1985) Biotechnology V 5: 69-76.

20. Wood T, Wilson C, Stewart C (1982) Biochemical Journal 205: 129-137.

21. Igarashi, Ishida T, Hori C, Masahiro (2008) Appl. Environ. Microbiol 74 (18).

22. Dipali P, Laxman R M, Rao (2012) Indian Journal of Biochemistry \& Biophysics Vol 49: 189-194.

23. Lynd L, Weimer P, Pretorius IS (2002) Microbial cellulose utilization: fundamentals and biotechnology. Microbiol Mol Biol Rev 66(4): 739

24. Jean-MGD (2003) patent EP 1272643 W02001070998A1.

25. Shafer T, Duffer F, Borchet T (2000) Proceeding of the IIICongress of Extremophiles, Hamburg, Germany, 306307.

26. Haki GD, Rakshit SK (2003) Developments in industrially important thermostable enzymes: a review. Biores Technol 89: 17-34

27. Yennamalli M, Rader J, Kenny J, Wolt D, Sen Z (2013) Endoglucanases: insights into thermostability for biofuel applications. Biotechnologies for Biofuels 6(1): 136. 
This work is licensed under Creative Commons Attribution 4.0 License DOI: $10.19080 /$ CTBEB.2017.04.555640
Your next submission with Juniper Publishers will reach you the below assets

- Quality Editorial service

- Swift Peer Review

- Reprints availability

- E-prints Service

- Manuscript Podcast for convenient understanding

- Global attainment for your research

- Manuscript accessibility in different formats

( Pdf, E-pub, Full Text, Audio)

- Unceasing customer service

Track the below URL for one-step submission https://juniperpublishers.com/online-submission.php 